\title{
Pengaruh Model Pembelajaran Course Review Horay (CRH) Terhadap Hasil Belajar Siswa
}

\author{
Nureva ${ }^{1}$, Siska Wulandari ${ }^{2}$ \\ 1,2 STKIP Al Islam Tunas Bangsa, Indonesia
}

Corresponding Author: Nureva, E-mail: nureva1981@gmail.com

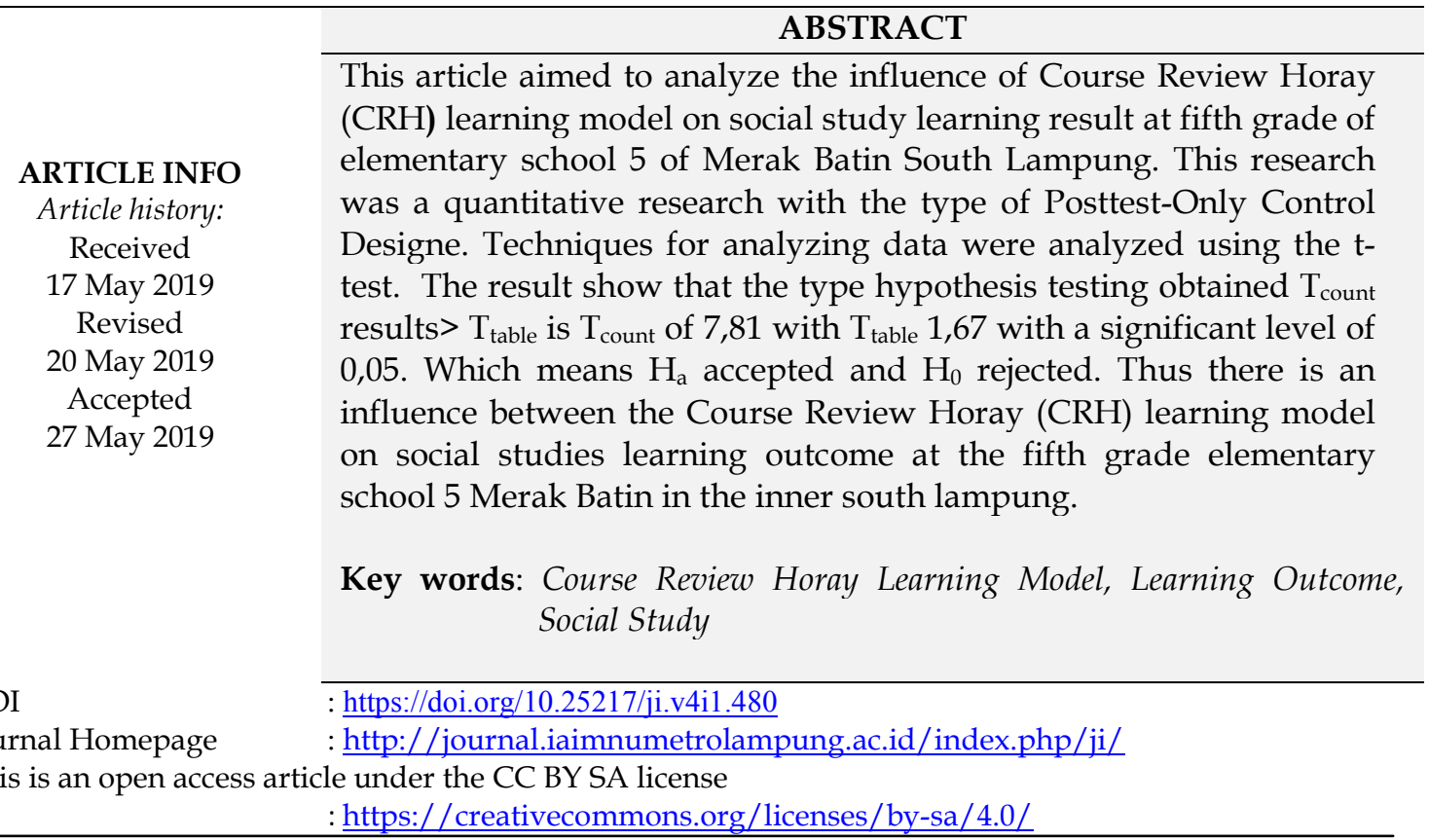

\section{PENDAHULUAN}

Pendidikan merupakan suatu wahana dan sarana yang baik dalam upaya pembinaan sumber daya manusia. Pendidikan merupakan kebutuhan utama sabagai bekal manusia di kehidupannya nanti, maka dari itu sudah selayaknya pendidikan mendapatkan perhatian, penanganan dan sebagai perioritas oleh pemerintah, masyarakat, keluarga dan seluruh pelaku pendidikan.

Proses pembelajaran yang baik dan tepat mempengaruhi kualitas pembelajaran. Dalam rangka meningkatkan mutu pendidikan yang bagus harapan yang ingin dicapai adalah pembelajar memahami apa yang dipelajari dan dapat diterapkan di kehidupan yang nyata. Oleh karena itu, guru di tuntut memiliki pengetahuan yang inovatif agar dalam proses pembelajaran bukan hanya guru yang aktif tetapi juga siswanya. Dengan demikian proses pembelajaran yang optimal akan terwujud (Kristin, 2018). 
Undang-undang No. 20 (2003) tentang SISDIKNAS, menyatakan bahwa pendidikan merupakan usaha sadar dan terencana untuk mewujudkan suasana belajar dan proses pembelajaran agar peserta didik secara aktif dan positif dalam kehidupan sekarang maupun yang akan datang dalam mengembangkan potensi dirinya untuk memiliki kekuatan spiritual keagamaan, pengendalian diri, kepribadian, kecerdasan, akhlak mulia, serta keterampilan yang diperlukan dirinya, masyarakat, bangsa dan negara.

Pendidik atau guru merupakan salah satu komponen penting dalam proses pembelajaran. Dalam undang-undang Nomor 14 tahun 2005 tentang guru dan dosen pasal 1 ayat 1 disebutkan bahwa guru adalah pendidik profesional dengan tugas utama mendidik, mengajar, membimbing, mengarahkan, melatih, menilai dan mengevaluasi peserta didik pada pendidikan anak usia dini jalur formal, pendidikan dasar dan menengah. Guru merupakan faktor penentu yang sangat dominan dalam pendidikan pada umumnya, karena guru memegang peran dalam proses pembelajaran dimana proses pembelajaran merupakan inti dari proses pendidikan secara keseluruhan.

Keberhasilan guru dalam mendidik dapat dilihat dari hasil belajar peserta didik setelah mengikuti proses pembelajaran di sekolah. Ada beberapa mata pelajaran yang perlu ditempuh peserta didik di sekolah dasar yaitu Pendidikan Kewarganegaraan, Bahasa Indonesia, Bahasa Inggris, Matematika, Ilmu Pengetahuan Alam, Ilmu Pengetahuan Sosial, Seni Budaya dan Keterampilan, Pendidikan Agama dan Penjaskes.

IPS sebagai salah satu program pendidikan tidak hanya menyajikan tentang konsep-konsep pengetahuan semata, namun IPS harus mampu membina peserta didik menjadi warga negara dan warga masyarakat. Mata pelajaran IPS mengkaji seperangkat peristiwa, fakta, konsep, dan generalisasi yang berkaitan dengan isu sosial. Pada jenjang SD/MI mata pelajaran IPS memuat materi Geografi, Sejarah, Sosiologi, dan Ekonomi. Melalui mata pelajaran IPS, peserta didik diarahkan untuk dapat menjadi warga negara Indonesia yang demokratis, dan bertanggung jawab, serta warga dunia yang cinta damai (Triana, 2016).

Menurut Gross dalam Trianto (2010) mengemukakan tujuan pendidikan IPS adalah untuk mempersiapkan siswa menjadi warga negara yang baik dalam kehidupannya dimasyarakat serta mengembangkan kemampuan siswa menggunakan penalaran dalam mengambil keputusan setiap persoalan yang dihadapainya. 
Dalam pelaksanaan pembelajaran IPS ini, seorang guru harus pandai dalam menciptakan suatu iklim pembelajaran sehingga siswa dapat aktif dalam mengembangkan potensi dirinya, misalnya siswa dapat belajar berinteraksi dengan teman-temannya di dalam kelas serta dapat secara aktif menyelesaikan permasalan-permasalahan yang diberikan oleh guru, tetapi pada saat ini setiap pelaksanaan pembelajaran berlangsung, kebanyakan guru selalu dijadikan sebagai pusat pembelajaran dan siswa hanya dijadikan sebagai objek pembelajaran yang menerima apa yang disampaikan oleh guru.

Hasil belajar merupakan indikator keberhasilan yang telah dicapai oleh siswa setelah mengikuti proses belajar mengajar. Hasil belajar siswa dipengaruhi oleh potensi siswa sendiri, sekolah, lingkungan masyarakat, dan dipengaruhi oleh kemampuan guru dalam melaksanakan kegiatan atau proses pembelajaran. Hasil belajar yang dicapai siswa meliputi beberapa ranah, yaitu ranah kognitif, ranah afektif, dan ranah psikomotorik. Prinsip yang mendasari penilaian hasil belajar yaitu bagi siswa dan guru untuk dapat meningkatkan kualitas pembelajaran. Pencapaian hasil belajar yang tidak maksimal dapat disebabkan oleh beberapa faktor, yaitu faktor yang berasal dari siswa dan faktor yang berasal dari guru (Suwarno, 2016).

Slameto (2013) menyatakan bahwa, belajar adalah suatu proses usaha yang dilakukan sesorang untuk perubahan tingkah laku yang baru secara keseluruhan, sebagai hasil pengalamannya sendiri dalam interaksi dengan lingkungannya. Perubahan yang terjadi dalam diri seseorang merupakan perubahan dalam belajar. Wingkel dalam Purwanto (2011) berpendapat bahwa "Hasil belajar adalah perubahan yang mengakibatkan manusia dalam sikap tingkah lakunya". Sedangkan menurut Purwanto (2011) menyatakan bahwa "Hasil belajar adalah perubahan tingkah laku yang terjadi setelah mengikuti proses belajar mengajar sesuai dengan tujuan pendidikan". Hasil belajar adalah dicapai dari proses belajar mengajar sesuai dengan tujuan pendidikan.

Purwanto (2011) telah mengatakan bahwa "Hasil belajar merupakan realisasi tercapainya tujuan pendidikan, sehingga hasil belajar yang diukur sangat tergantung pada tujuannya". Usman dalam Asep Jihad dan Abdul Haris (2013) menyatakan bahwa "Hasil belajar adalah yang dicapai siswa sangat erat kaitannya dengan rumusan tujuan intruksional yang direncanakan guru sebelumnya yang dikelompokkan kedalam tiga kategori yaitu: kognitif, afektif, dan psikomotorik".

Pada pembelajaran IPS hendaknya siswa dilibatkan secara langsung dalam proses pembelajaran. Sehingga siswa dapat dengan mudah memahami 
materi yang diajarkan oleh guru. Namun kenyataannya, dalam proses pembelajaran Ilmu Pengetahuan Sosial di sekolah dasar setiap kali pertemuan guru hanya menggunakan metode ceramah dan penugasan saja. Oleh karena itu, dibutuhkan suatu model pembelajaran yang efektif untuk meningkatkan hasil belajar IPS pada siswa kelas V.

Berdasarkan permasalahan di atas, Salah satu model pembelajaran yang dapat digunakan untuk meningkatkan hasil belajar IPS dan sesuai dengan karakteristik anak usia SD adalah model pembelajaran course review horay. Menurut Kurniasih dan Sani (2015) model pembelajaran course review horay adalah model yang dapat menciptakan suasana kelas menjadi meriah dan menyenangkan karena setiap siswa yang dapat menjawab dengan benar maka siswa tersebut diwajibkan berteriak "hore" atau yel-yel yang disepakati.

Selanjutnya Huda (2013) menjelaskan bahwa model pembelajaran course review horay membantu siswa untuk memahami konsep dengan baik melalui diskusi kelompok karena dengan model ini akan dilakukan pengujian pemahaman siswa pada materi pelajaran dan langsung dibahas sehingga siswa dapat langsung mengetahui jawabannya benar atau salah. Model ini melatih siswa menyelesaikan masalah, siswa yang paling terdahulu mendapatkan tanda benar berteriak hore atau yel-yel lainnya. Model pembelajaran course review horay juga memiliki kelebihan diantaranya menciptakan suasana pembelajaran yang menyenangkan karena diselingi dengan hiburan dan melatih kerja sama dalam menjawab soal yang diberikan oleh guru secara kelompok. Saat siswa terbiasa menjawab soal dan dilakukan pembahasan secara langsung, siswa akan lebih memahami materi pembelajaran sehingga diharapkan hasil belajarnya meningkat.

Adapun langkah-langkah model pembelajaran course review horay meliputi: (1) Guru menyampaikan kompetensi yang ingin dicapai, (2) Guru mendemostrasikan atau menyajikan materi, (3) Memberikan kesempatan siswa untuk tanya jawab, (4) Untuk menguji pemahaman siswa disuruh membuat kotak 9/ 16/ 25 sesuai dengan kebutuhan dan tiap kotak diisi angka sesuai dengan selera masing-masing siswa, (5) Guru membaca soal secara acak dan siswa menulis jawaban di dalam kotak yang nomornya disebutkan guru dan langsung didiskusikan, kalau benar diisi tanda benar $(\mathrm{P})$ dan salah diisi tanda silang (x), (6) Siswa yang telah mendapatkan tanda (P) vertikal, horisontal atau diagonal harus berteriak hore... atau yel-yel lainnya, (7) Nilai siswa dihitung dari jawaban benar jumlah hore yang diperoleh, (8) Penutup (Suprijono, 2013). Model pembelajaran course review horay ini dapat digunakan 
untuk berbagai mata pelajaran (PKn, Bahasa Indonesia, IPS, IPA, Matematika dll.

Sesuai dengan karakteristik siswa yang akan diteliti, bahwa siswa masih kurang dalam bersosialisasi dengan guru dan teman sekelasnya sehingga membuat keaktifan kelas dalam pembelajaran IPS menjadi kurang. Menurut Sugandi (2012) model pembelajaran kooperatif tipe CRH merupakan model pembelajaran yang dapat mendorong siswa ikut aktif dalam belajar IPS. Model pembelajaran ini merupakan cara belajar- mengajar yang lebih menekankan pada pemahaman materi yang diajarkan guru dengan menyelesaikan soal-soal. Pelaksanaan pembelajaran dengan menerapan model pembelajaran kooperatif tipe $C R H$, di mana aktivitas pembelajaran lebih banyak berpusat pada siswa dan guru hanya berperan sebagai penyampai informasi, fasilitator dan pembimbing yang mengurangi kebiasaan guru menerapkan pembelajaran konvensional dalam mengajar mata pelajaran IPS.

Course Review Horay adalah salah satu tipe dari model pembelajaran yang dapat mendorong siswa untuk ikut aktif dalam belajar. Penggunaan model ini merupakan cara belajar-mengajar inovatif yang lebih menekankan pada pemahaman materi yang diajarkan guru dengan menyelesaikan soal-soal diakhir pelajaran untuk mereview atau mengulang kembali materi pelajaran yang telah disampaikan guru.

Pembelajaran Course Review Horay dipilih dalam penelitian ini karena memiliki beberapa keunggulan diantaranya pembelajaran lebih menarik, medorong siswa untuk dapat terjun kedalam situasi pembelajaran, pembelajarannya tidak monoton sehingga siswa lebih antusias, termotivasi, dan semangat belajar karena suasana belajar lebih menyenangkan, serta dapat melatih kerjasama dan komunikasi yang baik antar siswa.

Keunggulan dari model pembelajaran Course Review Horay: 1) Siswa ikut aktif dalam belajar. 2) Melatih kerjasama dan kemampuan siswa dalam menyelesaikan masalah. 3) Suasana belajar dan interaksi yang menyenangkan membuat siswa lebih menikmati pelajaran sehingga siswa tidak mudah bosan untuk belajar. 4) Melatih siswa untuk mencapai tujuan-tujuan hubungan sosialyang pada akhirnya mempengaruhi prestasi akademik siswa. Kelemahan dari model pembelajaran Course Review Horay: 1) Siswa yang aktif dan pasif nilainya disamakan. Solusinya guru harus benar-benar mengontrol jalannya diskusi supaya siswa menjadi lebih aktif dalam diskusi. 2) Adanya peluang untuk curang. Solusinya pada lembar jawaban siswa tidak boleh ada coretcoret (Armirifi, 2012). 
Dengan melihat keunggulan dari model pembelajaran Course Review Horay diharapkan dapat membuat siswa menjadi tertarik dan lebih bersemangat serta antusias dalam mengikuti pelajaran IPS, dapat membimbing siswa untuk belajar lebih aktif lagi, dengan kondisi tersebut siswa lebih nyaman menikmati pelajaran dan tidak mudah bosan, maka siswa akan memahami materi pelajaran secara mendalam, sehingga dapat meningkatkan hasil belajar siswa.

Beberapa penelitian yang relevan pada penelitian ini, yaitu: penelitian yang dilakukan oleh Utami (2016) yang berjudul pengaruh model pembelajaran Course Review Horay (CRH) berbantuan media benda konkrit terhadap hasil belajar IPA. Tujuan dari penelitian ini diantaranya untuk mengetahui perbedaan hasil belajar IPA yang signifikan antara siswa yang belajar dengan model pembelajaran Course Review Horay (CRH) berbantuan media benda konkrit dengan siswa yang belajar dengan model pembelajaran konvensional. Hasil penelitian ini menunjukkan bahwa hasil belajar IPA siswa kelompok eksperimen (menggunakan $\mathrm{CRH}$ ) berpengaruh terhadap hasil belajar IPA pada siswa. Lebih lanjut penelitian yang dilakukan oleh Mediati (2016) dengan judul penggunaan model pembelajaran Course Review Horay dengan media Flipchart sebagai upaya meningkatkan hasil belajar PKn. Penelitian ini bertujuan untuk meningkatkan hasil belajar PKn melalui penggunaan model pembelajaran CRH dengan media flipchart. Hasil penelitian ini adalah penggunaan model pembelajaran $\mathrm{CRH}$ dengan media flipchart dapat meningkatkan hasil belajar PKn siswa kelas V SD Negeri 01 Bugel Salatiga.

Berdasarkan uraian di atas, melalui model pembelajaran Course Review Horay $(\mathrm{CRH})$ ini diharapkan dapat memengaruhi hasil belajar siswa sehingga hasil belajar siswa dapat tercapai secara optimal. Tujuan penelitian ini dilaksanakan adalah: "Untuk Mengetahui Pengaruh Penggunaan Model Pembelajaran Course Review Horay (CRH) Terhadap Hasil Belajar IPS Pada

Siswa Kelas V SDN 5 Merak Batin Kabupaten Lampung Selatan Tahun Pelajaran 2017/2018".

\section{METODE PENELITIAN}

Metode penelitian ini menggunakan penelitian eksperimen, Arikunto (2002) mengemukakan bahwa "penelitian eksperimen merupakan penelitian yang dimaksud untuk mengetahui ada tidaknya akibat dari suatu yang dikemukakan pada subjek selidik". Dengan kata lain, penelitian eksperimen mencoba meneliti ada tidaknya hubungan sebab akibat. Dalam penelitian ini, 
peneliti menggunakan jenis penelitian kuantitatif, yang bertujuan untuk menguji apakah ada pengaruh model Course Review Horay (CRH) dengan hasil belajar IPS.

Jenis penelitian ini termasuk jenis penelitian Quasi Experiment (eksperimen semu). Menurut Sugiyono (2014) Quasi Experiment adalah desain yang memiliki kelompok kontrol, tetapi tidak dapat mengontrol semua variabel-variabel luar yang mempengaruhi jalannya eksperimen. Penelitian ini berdesain Posttest-Only Control Designe, terdapat dua kelompok yang digunakan untuk penelitian, kelompok pertama diberi perlakuan $(X)$ dan kelompok yang lain tidak Kelompok yang diberi perlakuan disebut kelas eksperimen dan kelompok yang tidak diberi perlakuan disebut kelas kontrol.

Gambar (Figure) 1.

Desain Penelitian

\begin{tabular}{|ccc|}
\hline $\mathbf{R}$ & $\mathbf{X}$ & $\mathbf{O}_{2}$ \\
$\mathbf{R}$ & & $\mathbf{O}_{4}$ \\
\hline
\end{tabular}

Keterangan:

$\mathrm{R}=$ Random

$\mathrm{X}=$ Diberi Perlakuan

$\mathrm{O}_{2} \quad=$ Hasil Belajar (Kelas Eksperimen)

$\mathrm{O}_{4} \quad=$ Hasil Belajar (Kelas Kontrol)

Penelitian ini menggunakan teknik sampling jenuh untuk menentukan sampel yang akan diambil. Menurut Sugiyono (2011), Sampling Jenuh adalah sampel yang mewakili jumlah populasi. Penggunaan sampel ini dilakukan karena jumlah populasi kecil atau kurang dari 100. Jumlah siswa hanya 56 orang, maka seluruh siswa dijadikan sampel penelitian.

Peneliti menggunakan 2 kelas sebagai sampel. Kelas pertama disebut kelas eksperimen dengan pemberian perlakuan model pembelajaran Course Review Horay (CRH) dan kelas kedua kelas kontrol tidak diberikan perlakuan model pembelajaran Course Review Horay (CRH). Kelas yang terpilih sebagai kelas eksperimen adalah kelas V-A sebanyak 28 siswa dan kelas yang terpilih sebagai kelas kontrol adalah kelas V-B sebanyak 28 siswa. 
Variabel penelitian pada penelitian ini yaitu variabel $X$ adalah model pembelajaran Course Review Horay (CRH) dan variabel Y adalah hasil belajar. Pengumpulan data penelitian ini menggunakan dokumentasi, tes dan angket.

Uji coba instrumen pada penelitian ini menggunakan uji validitas dengan rumus Product Moment.

$r_{x y}=\frac{N \sum X Y-\left(\sum X\right)\left(\sum Y\right)}{\sqrt{\left\{N \sum X^{2}-\left(\sum X\right)^{2}\right\}}\left\{N \sum Y^{2}-\left(\sum Y\right)^{2}\right\}}$

Dengan hasil uji validitas tes dan angket yang berjumlah 20 butir soal dan 20 butir pernyataan angket yang dinyatakan valid. Dengan uji reliabilitas menggunakan rumus Sperman Brown Arikunto (2002):

$$
r_{i}=\frac{2 r_{b}}{\left(1+r_{b}\right)}
$$

Untuk uji prasyarat analisis menggunakan uji normalitas dan uji homogenitas. Jika dari hasil uji normalitas dan uji homogenitas memenuhi syarat, maka dilanjutkan dengan uji hipotesis menggunakan uji-t sampel. Teknik analisis uji hipotesis merupakan langkah yang digunakan untuk menjawab rumusan masalah dalam penelitian dan tujuannya untuk mendapat kesimpulan dari suatu penelitian.

\section{HASIL PENELITIAN DAN PEMBAHASAN}

Berdasarkan hasil belajar nilai posttest diketahui yang diperoleh selanjutnya dianalisis, namun sebelumnya dilakukan uji prasyarat analisis data terlebih dahulu yang meliputi uji normalitas dan homogenitas.

Uji normalitas pada data nilai kelas kontrol hasil belajar posttest, penelitian memperoleh nilai $\chi_{\text {hit }}^{2}=7,21$. Sehingga dari daftar ditribusi frekuensi dapat diketahui banyaknya kelas $(\mathrm{K})=6 \mathrm{dk}$ untuk ditribusi $\chi^{2}=3$. Maka diperoleh $\chi^{2}(0,95)(3)=7,81$. Dengan demikian, terlihat $\chi_{\text {hit }}^{2}<\chi_{\text {daf }}^{2}$ maka $\mathrm{H}_{0}$ diterima yang berati data posttest berdistribusi normal.

Perolehan frekuensi uji normalitas nilai posttest kelas kontrol atau kelas yang tidak diberikan perlakuan menggunakan model pembelajaran Course Review Horay (CRH) dapat dilihat dalam tabel dibawah ini: 
Tabel 1. Nilai Posttest Kelas Kontrol

\begin{tabular}{|l|l|}
\hline \multicolumn{1}{|c|}{ Kategori } & $\begin{array}{l}\text { Posttest } \\
\text { kelas kontrol }\end{array}$ \\
\hline Rerata & 57 \\
\hline Nilai tertinggi & 70 \\
\hline Nilai terendah & 40 \\
\hline Standar deviasi & 8,74 \\
\hline Median & 55 \\
\hline Modus & 50 \\
\hline
\end{tabular}

Sedangkan untuk uji normalitas hasil belajar posttest kelas eksperimen, penelitian memperoleh nilai $\chi_{\text {hit }}^{2}=6,03$. Sehingga dari daftar ditribusi frekuensi dapat diketahui banyaknya kelas $(\mathrm{K})=6 \mathrm{dk}$ untuk ditribusi $\chi^{2}=3$. Maka diperoleh $\chi_{(0,95)(3)}^{2}=7,81$. Dengan demikian, terlihat $\chi_{\text {hit }}^{2}<\chi_{\text {daf }}^{2}$ maka $\mathrm{H}_{0}$ diterima yang berati data posttest eksperimen berdistribusi normal.

Perolehan frekuensi uji normalitas nilai posttest kelas eksperimen atau kelas yang diberi perlakuan menggunakan model pembelajaran Course Review Horay $(\mathrm{CRH})$ dapat dilihat dalam tabel dibawah ini:

Tabel 2. Nilai Post test Kelas Eksperimen

\begin{tabular}{|l|l|}
\hline Kategori & $\begin{array}{l}\text { Post test } \\
\text { kelas } \\
\text { eksperimen }\end{array}$ \\
\hline Rerata & 75 \\
\hline $\begin{array}{l}\text { Nilai } \\
\text { tertinggi }\end{array}$ & 95 \\
\hline $\begin{array}{l}\text { Nilai } \\
\text { terendah }\end{array}$ & 65 \\
\hline $\begin{array}{l}\text { Standar } \\
\text { deviasi }\end{array}$ & 7,82 \\
\hline Median & 72 \\
\hline Modus & 70 \\
\hline
\end{tabular}

Diketahui deskripsi nilai posttest kelas eksprimen > posttest kelas kontrol. Nilai rataan posttest kelas eksperimen $=75$ lebih tinggi dibandingkan dengan nilai rataan posttest kelas kontrol $=57$. Perolehan nilai tertinggi posttest kelas eksprimen $=95>$ posttest kelas kontrol $=70$ dan nilai terendah posttest kelas 
eksperimen $=65>$ posttest kelas kontrol $=40$, serta pemerolehan standar deviasi posttest kelas eksperimen $=8,74>$ posttest kelas kontrol $=7,82$.

Pada uji normalitas dihasilkan berdistribusi normal maka uji prasyarat dilanjutkan ke uji homogenitas. Pada uji homogenitas hasil analisis uji kesamaan diperoleh $\mathrm{F}_{\text {hitung }}=1,11$ sedangkan berdasarkan tabel distribusi $\mathrm{F}$ dengan $\mathrm{N}=28$ dan taraf nyata $0,05 \mathrm{~F}_{\text {tabel }}=1,90$, karena $\mathrm{F}_{\text {hitung }} \leq \mathrm{F}_{\text {tabel }}$ maka $\mathrm{H}_{0}$ diterima sehingga data posttest mempunyai varians yang sama (homogen).

Selanjutnya setelah uji prasyarat telah selesai dan telah lulus uji maka selanjutnya akan dilanjutkan dengan uji hipotesis dengan menggunakan rumus uji t-tes uji hipotesis untuk mengetahui pengaruh model pembelajaran Course Review Horay $(\mathrm{CRH})$ terhadap hasil belajar IPS.

Dari perhitungan tersebut, diperoleh nilai $\mathrm{T}_{\text {hit }}$ sebesar 7,81. Dengan $\mathrm{db}=$ $\mathrm{n}_{\mathrm{x}}+\mathrm{n}_{\mathrm{y}}=28+28-2=54$, maka dapat diketahui nilai $\mathrm{T}_{\text {Tabel }}$ sebesar 1,67 sesuai dengan penafsiran $\mathrm{t}$-tes yakni hipotesis penelitian diterima apabila $\mathrm{T}_{\text {hit }}>\mathrm{T}_{\text {tabel }}$ dengan hasil 7,81 > 1,67 maka $\mathrm{H}_{\mathrm{a}}$ diterima.

Hasil penelitian yang telah dilakukan menghasilkan perbedaan yang signifikan terhadap hasil belajar IPS siswa yang menggunakan model pembelajaran Course Review Horay ( $C R H)$ dengan yang tidak menggunakan model pembelajaran Course Review Horay ( $C R H)$. Sesuai dengan kretria hasil penghitungan uji t-tes $T_{\text {hit }}>$ 7,81 lebih besar dari 1,67 maka $\mathrm{H}_{\mathrm{a}}$ diterima.

Berdasarkan hasil dari serangkaian pengujian, dapat disimpulkan bahwa hasil belajar peserta didik di kelas eksperimen lebih baik daripada di kelas kontrol. Artinya, keberhasilan proses pembelajaran dengan menggunakan model pembelajaran Course Review Horay (CRH) lebih efektif daripada model konvensional. Hal ini sejalan dengan pendapat Shoimin (2014: 55) yang menyatakan kelebihan model pembelajaran Course Review Horay (CRH), yaitu pembelajarannya menarik dan mendorong siswa untuk dapat terkibat di dalamnya, tidak monoton karena diselingi hiburan, sehingga suasana tidak membosankan, suasana pembelajaran yang menyenangkan, sehingga semangat belajar meningkat, dan keterampilan kerjasama antarpeserta didik lebih terlatih. Kurniasih, Imas dan Berlin Sani (2015: 80) juga mengemukakan kelebihan model pembelajaran Course Review Horay (CRH) yaitu pembelajaran menarik untuk di ikuti, mendorong siswa untuk dapat terjun langsung atau terlibat dalam proses pembelajarannya, kegiatan pembelajaran yang dilakukan tidak terkesan monoton karena diselingi hiburan yang lebih memotivasi siswa mengikuti sengkaian pembelajaran, suasana pembelajaran tidak menegangkan sehingga siswa tidak merasa takut untuk bertanya dan mengungkapkan pendapat mengenai konsep materi yang diberikan, proses kegiatan belajar 
mengajar berlangsung menyenangkan sehingga siswa lebih bersemangat dalam mengikuti pembelajaran dikelas dan melatih siswa dalam bekerja sama di dalam kelas, karena dalam prosesnya siswa di bentuk menjadi beberapa kelompok kerja.

Melalui pembelajaran Course Review Horay (CRH), siswa dilatih untuk mampu bekerjasama dengan anggota kelompok yang lain. Keterampilan kerjasama siswa termasuk dalam keterampilan sosial. Mereka berkomunikasi secara interaktif untuk memecahkan masalah. Selain itu, siswa juga dilatih untuk berkompetisi secara sehat dengan berdasar pada nilai-nilai sosial. Dengan demikian, dapat disimpulkan bahwa pembelajaran Course Review Horay $(C R H)$, dapat digunakan sebagai jembatan untuk mencapai tujuan pembelajaran IPS. Menurut Susanto (2013: 145) menjelaskan bahwa tujuan utama pembelajaran IPS adalah untuk mengembangkan potensi peserta didik agar peka terhadap masalah sosial yang terjadi di masyarakat, memiliki sikap mental positif terhadap perbaikan segala ketimpangan yang terjadi, dan terampil mengatasi setiap masalah yang terjadi sehari-hari baik yang menimpa dirinya sendiri maupun menimpa masyarakat.

Berdasarkan pemaparan pembahasan di atas, dapat disimpulkan bahwa model pembelajaran Course Review Horay $(C R H)$ efektif untuk meningkatkan hasil belajar peserta didik pada mata pelajaran IPS. Model pembelajaran Course Review Horay $(\mathrm{CRH})$ menekankan pada pemahaman materi, penanaman nilainilai moral, dan keterampilan sosial pada peserta didik, sehingga secara tidak langsung mampu membentuk karakter peserta didik. Dengan demikian, peserta didik tidak hanya memperoleh pengetahuan, namun juga mempunyai sikap, keterampilan, dan kepekaan untuk menghadapi masalah-masalah sosial yang dihadapinya dalam kehidupan.

\section{KESIMPULAN}

Berdasarkan hasil penelitian dan pembahasan dapat disimpulkan bahwa terdapat pengaruh yang signifikan antara model Pembelajaran Course Review Horay terhadap hasil belajar IPS pada siswa kelas V SDN 5 Merak Batin Kabupaten Lampung Selatan. 


\section{DAFTAR PUSTAKA}

Arifatun Nahar, Arifatun., Sulistyaningsih, Dwi., dan Purnomo, Eko Andri. 2016. Keefektifan Model Pembelajaran Course Review Horay dengan Pendekatan Kontekstual terhadap Kemampuan Komunikasi Matematis pada Materi Segitiga Kelas VII. Jurnal Karya Pendidikan Matematika Vol 3 No 1 (48-59).

Arikunto, Suharsimi. 2002. Prosedur Penelitian Suatu Pendekatan Praktik. Jakarta: Rineka Cipta.

Huda, Miftahul. 2013. Model-model pengajaran dan pembelajaran. Yogyakarta: Pustaka Pelajar.

Hutauruk, Pindo dan Simbolon, Rinci. 2018. Meningkatkan Hasil Belajar Siswa Dengan Alat Peraga Pada Mata Pelajaran IPA Kelas IV SDN Nomor 14 Simbolon Purba. School Education Journal Vol 8 No 2 (121-129).

Jihad, Asep dan Haris Abdul. 2013. Evaluasi Pembelajaran. Yogyakarta: Multi Pressido.

Kurniasih, Imas dan Berlin Sani. 2015. Ragam Pengembangan Model Pembelajaran untuk Peningkatan Profesionalitas Guru. Surabaya: Kata Pena

Kristin, Firosalia. 2018. Meta Analisis Pengaruh Model Pembelajaran Role Playing Terhadap Hasil Belajar IPS. Jurnal Refleksi Edukatika, 8 (2): 172.

Maryam, Siti., Hasbi, Muh., dan Hamid, Abd. 2016. Penerapan Model Pembelajaran Kooperatif Tipe Course Review Horay Untuk Meningkatkan Hasil Belajar Siswa Pada Materi Keliling dan Luas Persegi Panjang di Kelas VII SMP Negeri 2 Marawola. Jurnal Elektronik Pendidikan Matematika Tadulako, Vol 4 No 1 (116-130).

Mediatati, Nani dan Suryaningsih, Istiana. 2016. Penggunaan Model Pembelajaran Course Review Horay dengan Media Flipchart Sebagai Upaya Meningkatkan Hasil Belajar PKn. Jurnal Ilmiah Sekolah Dasar. Vol. 1 No 2 (113-121).

Purwanto, 2011. Evaluasi Hasil Belajar. Yogyakarta: Pustaka Pelajar.

Shoimin, Aris. 2014. Model Pembelajaran Inovatif. Jakarta: Ar. Ruzz Media.

Slameto. 2013. Belajar dan Faktor-faktor yang Mempengaruhi. Jakarta: Rineka Cipta.

Sugiyono. 2011. Penelitian Kualitatif, Kuantitatif Dan RED. Bandung: Alfabeta. . 2014. Penelitian Kualitatif, Kuantitatif Dan REDD. Bandung: Alfabeta. 
Susanto. A. 2013. Teori Belajar Dan Pembelajaran Di Sekolah Dasar. Jakarta: Kencana.

Suwarno, Agus. 2016. Penerapan Metode Inquiry Tehadap Hasil Belajar Siswa Pada Mata Pelajaran IPS Terpadu Dalam Materi Keragaman Flora dan Fauna di Indonesia di Kelas VII SMP Negeri 1 Tebas. Jurnal Refleksi Edukatika. 7(1):13.

Triana, Lilis. 2016. Penggunaan Strategi Mind Mapping Berbasis Multimedia Untuk Meningkatkan Hasil Belajar IPS Pada Siswa Kelas V SDN 1 Wonorejo Demak. Jurnal Refleksi Edukatika, 7 (1):37.

Trianto. 2012. Model-model Pembelajaran Inovatif Berorientasi Konstruktivistik. Jakarta: Prestasi Pustaka

Undang-undang Nomor 14 Tahun 2005 tentang Guru dan Dosen.

Undang-undang Sisdiknas Nomor 20 Tahun 2003, Tentang Sistem Pendidikan nasional.

Utami, Putu Desy Kompyang Sari dkk. 2016. Pengaruh Model Pembelajaran Course Review Horay (CRH) Berbantuan Media Konkrit Terhadap Hasil Belajar IPA. E-Journal PGSD Universitas Pendidikan Ganesha Vol 4 No 1 (111). 